\title{
Gas Exchange, Chlorophyll and Growth Responses of Betula Platyphylla Seedlings to Elevated $\mathrm{CO}_{2}$ and Nitrogen
}

\author{
Xizhu Zhao \\ Key laboratory of Forest Plant Ecology, Ministry of Education \\ Northeast Forestry University, 26 Hexing Road, Harbin 150040, China \\ Tel: 86-451-8219-1662 E-mail: woshizhaoxizhu@126.com \\ Zijun Mao (Corresponding author) \\ Key laboratory of Forest Plant Ecology, Ministry of Education \\ Northeast Forestry University, 26 Hexing Road, Harbin 150040, China \\ Tel: 86-451-8219-1662Ｅ-mail: zijunm@yahoo.com.cn
}

Juan Xu

Forest Botanical Garden of Heilongjiang Province

Harbin 150040, China

E-mail: woshizhaoxizhu@126.com

This study was supported by the Chinese Nature Scientific Fund, project no. 30471372.

\begin{abstract}
Effects of elevated $\left[\mathrm{CO}_{2}\right]$ and nitrogen nutrition on leaf gas exchange, chlorophyll content and growth in Betula platyphylla seedlings were studied. The seedlings were grown in the ambient $\left[\mathrm{CO}_{2}\right]\left(\mathrm{AC}, 350 \mu \mathrm{mol} \mathrm{mol}{ }^{-1}\right)$ and elevated $\left[\mathrm{CO}_{2}\right]\left(\mathrm{EC}, 700 \mu \mathrm{mol} \mathrm{mol}^{-1}\right)$ growth chambers, with three levels of nitrogen: $\mathrm{LN}\left(0 \mathrm{mmol} \mathrm{L}^{-1} \mathrm{~N}\right), \mathrm{MN}\left(1.5 \mathrm{mmol} \mathrm{L}^{-1} \mathrm{~N}\right)$ and $\mathrm{HN}\left(3 \mathrm{mmol} \mathrm{L}^{-1} \mathrm{~N}\right)$. HN increased photosynthesis $\left(P_{\max }\right)$, photochemical efficiency of PSII $\left(F_{\mathrm{v}} / F_{\mathrm{m}}\right)$ and intercellular $\left[\mathrm{CO}_{2}\right]\left(C_{\mathrm{i}}\right)$ by $120 \%, 8 \%$ and $11 \%$ than the LN. EC significantly increased $P_{\max }$ and $C_{\mathrm{i}}$ by $37 \%$ and $57 \%$ compared to the AC. The interaction of EC and LN was significant increased by $85 \%$ than the $\mathrm{AC}+\mathrm{MN}$, and could be attributed to both inhibition of photosynthetic light reactions and carboxylation activity of Rubisco. In AC and EC, total biomass were 3.2 and 5.1 times greater in HN compared to LN. Root biomass increased significantly in HN level under both AC and EC. Chlorophyll (Chl) $a$ and $\mathrm{Chl} b$ increased with increasing $\mathrm{N}$ availability.
\end{abstract}

Keywords: Betula platyphylla Suk., $C_{\mathrm{i}}$, Elevated $\left[\mathrm{CO}_{2}\right], F_{\mathrm{v}} / F_{\mathrm{m}}$, Nitrogen

\section{Introduction}

Elevated $\left[\mathrm{CO}_{2}\right]$ usually enhances photosynthesis (Teskey, 1997, pp.375; Matamala and Drake, 1999, pp.93; Elizabeth et al., 2007, pp.258), plant growth and carbon accumulation (King et al., 1996, pp.635). However, the magnitude of the response is generally affected by other environmental factors. Nitrogen availability often limits plant growth more than the availability of other nutrients (Crawford and Glass, 1998, pp.389). Most studies have shown that the degree of photosynthetic stimulation in response to elevated $\left[\mathrm{CO}_{2}\right]$ was larger in seedlings receiving high- $\mathrm{N}$ rates than in seedlings receiving low-N rates (Murray et al., 2000, pp.421). Murray et al. (2000, pp.421) reported that chlorophyll concentration increased with increasing $\mathrm{N}$ supply, however others have found that chlorophyll concentration was unaffected by growth $\left[\mathrm{CO}_{2}\right]$ (Carswell et al. 2000, pp.977). Most studies have shown that elevated $\left[\mathrm{CO}_{2}\right]$ increased biomass accumulation in seedlings supplied with high levels of available $\mathrm{N}$, but it had little or no effect on seedlings growing in soil with low $\mathrm{N}$ availability (Murray et al., 2000, pp.421; Maillard et al., 2001, pp.163). To understand the response of plants to elevated $\left[\mathrm{CO}_{2}\right]$ it is important to consider nutrient acquisition as well.

White birch (Betula platyphylla Suk.) is a pioneer boreal tree species of northeastern Asia, plays an important role in the boreal forest region. However, its ecophysiological characteristics have been little studied. The purpose of this study 
was to investigate the response of white birch to elevated $\left[\mathrm{CO}_{2}\right]$ and different nitrogen regimes, as well as their potential interactions, focusing on how these factors influence gas exchange, chlorophyll content and biomass accumulation. We hypothesized that elevated $\left[\mathrm{CO}_{2}\right]$ would enhance nitrogen absorption and chlorophyll concentration at all levels of nitrogen availability.

\section{Materials and methods}

Seeds of white birch were obtained from a local experimental forest near Northeast Forestry University of China (NEFUC) $\left(45^{\circ} \mathrm{N}, 127^{\circ} \mathrm{E}\right)$ and were grown in a greenhouse of the key laboratory of forest plant ecology of NEFUC. Forty-five days after germination, one seedling was transferred to one pot $(16 \mathrm{~cm}$ diameter, $16 \mathrm{~cm}$ height) containing black soil and sand (2:1) obtained from an arboretum close to the laboratory. Three different nitrogen treatments, with optimum application rate of 1.5 and lower of 0 and higher of $3 \mathrm{mmol} \mathrm{L}^{-1} \mathrm{~N}$ liquid fertilizer respectively, were maintained. $\mathrm{NH}_{4} \mathrm{NO}_{3}$ was used as the nitrogen source. Other nutrients were supplied at the same time in equal amounts to every pot using Hoagland's solution (Hoagland and Arnon, 1950, pp.32). Five pots of each nitrogen treatment were transferred to ambient $\left[\mathrm{CO}_{2}\right]$ chamber $(\mathrm{AC}, 350 \mathrm{ppm})$ and elevated $\left[\mathrm{CO}_{2}\right]$ chamber $(\mathrm{EC}, 700 \mathrm{ppm})$. The plants were grown in climatic chambers (Conviron E8, Canada) under a temperature and light regime that simulated local natural conditions (Figure 1). The experiment lasted for three months (July-September, 2006).

Net photosynthesis $\left(P_{\max }\right)$, dark respiration rate $\left(R_{\mathrm{d}}\right)$ and chlorophyll fluorescence were measured on the uppermost fully expanded leaf of the main branch, using a Li-6400 infra-red gas analyser (Li-Cor, Lincoln NE, USA). $P_{\text {max }}$ was measured at $1400 \mu \mathrm{mol} \mathrm{m} \mathrm{m}^{-2} \mathrm{~s}^{-1}$ photosynthetically active radiation (PAR) and $R_{\mathrm{d}}$ was measured after the leaves had acclimated to the dark for about 5 minutes. Chlorophyll fluorescence of the leaves was determined using a fluorometer (Li-6400-40, Li-Cor, Lincoln NE, USA). after adapted in darkness for at least 20 minutes to allow relaxation of fluorescence quenching associated with thylakoid membrane energization (Jung, 1998, pp.71). The ratio of variable to maximum fluorescence $\left(F_{\mathrm{v}} / F_{\mathrm{m}}\right)$ derived from the measurement was used as a measure of the maximum photochemical efficiency of PSII (Butler, 1978, pp.348).

The chlorophyll content of leaves was determined by the dimethyl sulphoxide (DMSO) method (Küster, 2004, pp.114) Plants were divided into leaf, stem, branch and root. Root was divided into primary $(<1 \mathrm{~mm})$, secondary $(1 \mathrm{~mm}-2 \mathrm{~mm})$ and tap (>2mm) root (King, 1996, pp.637). All tissues were dried in an oven at $70{ }^{\circ} \mathrm{C}$ to constant weight.

Five replicates of each treatment were evaluated by two-way analysis of variance (ANOVA) for $P_{\text {max }}, R_{\mathrm{d}}, F_{\mathrm{v}} / F_{\mathrm{m}}, C_{\mathrm{i}}, \mathrm{Chl}$ and biomass. When the interaction between nutrient and $\left[\mathrm{CO}_{2}\right]$ treatments was significant for a given parameter, a LSD test was conducted at the 0.05 significance level. The comparisons of AC and EC treatments were mean values for three nitrogen levels, respectively.

\section{Results}

\subsection{Photosynthetic parameters}

Under ambient $\left[\mathrm{CO}_{2}\right]$, increasing $\mathrm{N}$ availability increased $P_{\max }$ (Figure 2, Table 1). Compared with the LN treatment, the HN treatment increased $P_{\max }$ by $120 \%$. The HN treatment also had higher $F_{\mathrm{v}} / F_{\mathrm{m}}$ than either the LN or medium N $(\mathrm{MN})$ treatments, increased by $8 \%$ relative to $\mathrm{LN}$. $C_{\mathrm{i}}$ was $11 \%$ and $15 \%$ higher than in the $\mathrm{LN}$ and $\mathrm{MN}$ treatment, which were 302 and $291 \mu \mathrm{mol} \mathrm{mol}{ }^{-1}$, respectively. Thus, under ambient $\left[\mathrm{CO}_{2}\right]$, higher nitrogen availability promoted photosynthetic capacity of birch seedlings in both the light and dark reactions. There were no statistically significant differences in the rates of respiration among the different nitrogen levels (Figure 2D), indicating that leaf-level carbon use efficiency increased. Elevated $\left[\mathrm{CO}_{2}\right]$ increased $P_{\max }, F_{\mathrm{v}} / F_{\mathrm{m}}$ and $C_{\mathrm{i}}$ by $37 \%, 2 \%$ and $57 \%$, respectively. There were some interactions between $\left[\mathrm{CO}_{2}\right]$ and nitrogen availability (Figure 2). The LN treatment caused a large increase in $C_{\mathrm{i}}$ in elevated $\left[\mathrm{CO}_{2}\right](P<0.01)$, but not in ambient $\left[\mathrm{CO}_{2}\right]$. The value of $C_{\mathrm{i}}$ in the $\mathrm{EC}+\mathrm{LN}$ treatment was $85 \%$ higher than in the $\mathrm{AC}+\mathrm{MN}$ treatment.

\subsection{Chlorophyll content}

Chlorophyll content increased with increasing nitrogen level (Table 2). The pattern was the same as the change in $P_{\max }$. In $\mathrm{AC}$ treatment, $\mathrm{HN}$ treatment increased the $\mathrm{Chl} a$ and $\mathrm{Chl} b$ by $25 \%$ and $38 \%$ than the $\mathrm{MN}$ treatment $(P>0.05)$. And LN treatment reduced the $\mathrm{Chl} a$ and $\mathrm{Chl} b$ by $66 \%$ and $61 \%$ than the $\mathrm{MN}$ treatment $(P<0.05)$. There was no significant difference on the Chl $a+b$ among the different nitrogen treatments. EC treatment had no significant effect on chlorophyll content. Neither elevated $\mathrm{CO}_{2}$ nor nitrogen treatment had any significant effect on the Chl $b$ content. However, the LN treatment decreased $\mathrm{Chl} a+b$ by $72 \%$ although the decrease was significant only under the EC treatment.

\subsection{Biomass}

Nitrogen treatment had significant effects on the total and component biomass of the seedlings $(P<0.0001)($ Table 1 and Figure 3). The $\left[\mathrm{CO}_{2}\right]$ treatment affected total biomass $(P=0.068)$, total root $(P=0.008)$ and secondary $(P=0.003)$ root biomass. There were no significant differences in stem, leaf or primary root biomass between the two $\left[\mathrm{CO}_{2}\right]$ treatments, 
indicating that the main growth response to $\left[\mathrm{CO}_{2}\right]$ was in secondary roots. In addition, there were no $\left[\mathrm{CO}_{2}\right]$ and $\mathrm{N}$ interactions for any of the biomass parameters, except for stem.

In ambient $\left[\mathrm{CO}_{2}\right]$, compared to the $\mathrm{MN}$ treatment, $\mathrm{HN}$ treatment caused an increase in total biomass and root, stem, leaf and primary root biomass of $80 \%, 21 \%, 150 \%, 176 \%$ and $58 \%$, respectively but a decrease in secondary root biomass by $4 \%$. The LN treatment decreased the response by $181 \%, 163 \%, 186 \% 300 \%, 153 \%$ and $176 \%$ in total, root, stem, leaf, secondary and primary root biomass, respectively compared to the $\mathrm{MN}$ treatment.

Elevated $\left[\mathrm{CO}_{2}\right]$ treatment caused an increase by $16 \%, 11 \%, 18 \%, 52 \%, 22 \%$ increase in total, root, stem, leaf and secondary root biomass, respectively, but an reduce by $2 \%$ in primary root biomass. There was significant interaction between $\left[\mathrm{CO}_{2}\right]$ and nitrogen availability on stem $(P<0.0001)$ (Table 1 and Figure 3$)$. The EC+HN treatment increased stem biomass by $103 \%$ and the $\mathrm{EC}+\mathrm{LN}$ treatment reduced that by $47 \%$ relative to $\mathrm{AC}+\mathrm{MN}$ treatment.

\section{Discussion}

Our study suggests that nitrogen availability had more important effects on the growth of white birch seedlings than elevated $\left[\mathrm{CO}_{2}\right]$. The increase in biomass with higher $\mathrm{N}$ availability corresponded with increased $P_{\max }$ and a lack of increase in $R_{\mathrm{d}}$. Increased soil nitrogen concentration caused a great enhancement in photosynthesis in the birch seedlings, suggesting this was the main cause of the growth response. Increased $\mathrm{N}$ availability also enhanced $F_{\mathrm{v}} / F_{\mathrm{m}}$. $F_{\mathrm{v}} / F_{\mathrm{m}}$ reflects the potential quantum efficiency of PSII and is used as an indicator of plant photosynthetic performance15. Increased nitrogen supply to plants has been reported to cause an increase in $F_{\mathrm{v}} / F_{\mathrm{m}}$ in many plants (Kaakinen et al., 2004, pp.712). In ambient $\left[\mathrm{CO}_{2}\right], \mathrm{HN}$ also increased intercellular $\mathrm{CO}_{2}$ concentration, indicating that stomatal conductance was higher. The $\mathrm{HN}$ treatment also increased $P_{\max }$, thus, in ambient $\left[\mathrm{CO}_{2}\right]$ the $\mathrm{HN}$ treatment promoted both the light and carbon reactions synchronously, greatly enhancing the photosynthetic capacity of the birch seedlings. Nitrogen is often the most limiting mineral element in plants and the crucial component of chlorophyll $(\mathrm{Li}$, 2000, pp.190) so it is not surprising that chlorophyll concentration was strongly affected by nitrogen availably. These results are agreement with the finding of Guo et al. (2005, pp.589) who reported that total chlorophyll content was lower in larch seedlings receiving low $\mathrm{N}$ fertilization rates than in seedlings receiving high-N rates. There was a good correlation between chlorophyll content, $F_{\mathrm{v}} / F_{\mathrm{m}}$ and photosynthetic capacity in the birch leaves. In contrast, dark respiration did not significantly differ among the six treatments, suggesting that higher $\mathrm{N}$ fertilization enhanced carbon use efficiency.

In the present study, $\mathrm{EC}+\mathrm{HN}$ and $\mathrm{EC}+\mathrm{MN}$ treatment promoted total biomass accumulation of birch seedlings to a greater extent than the EC-LN ( $P=0.003$ and $P=0.001$ ) (Figure 3). This is consistent with Uprety and Mahalaxmi $(2000$, pp.272) who reported that nitrogen fertilizer significantly increased the dry weights of biomass including leaves (41\%), stems $(15 \%)$ and roots $(11 \%)$ in elevated $\left[\mathrm{CO}_{2}\right]$ conditions. EC increased leaf, stem and root growth over $\mathrm{AC}$, and the pattern were the same in the $\mathrm{LN}, \mathrm{MN}$ and $\mathrm{HN}$ treatments.

Elevated $\left[\mathrm{CO}_{2}\right]$ increased $P_{\max }$ in $\mathrm{MN}$ and $\mathrm{HN}$ treatment, but not in $\mathrm{LN}$ treatment. Elevated $\left[\mathrm{CO}_{2}\right]$ significantly increased $C_{\mathrm{i}}$ in LN and MN treatments (Table 1, Figure 2). The higher $C_{\mathrm{i}}$ and lack of change in $P_{\max }$ in the EC+LN treatment indicated that $\mathrm{N}$ availability was more limiting to photosynthetic capacity than the $\left[\mathrm{CO}_{2}\right]$. Elevated $\left[\mathrm{CO}_{2}\right]$ reduced the $\mathrm{Chl} a+b$ and $\mathrm{Chl} a$. This is consistent with Luomala et al. (2003, pp.657) who reported that elevated $\left[\mathrm{CO}_{2}\right]$ reduced chlorophyll content. Uprety and Mahalaxmi (2000, pp.274) attributed such a reduction to the reduction in Rubisco.

Typically, elevated $\left[\mathrm{CO}_{2}\right]$ enhances the rate of photosynthesis by promoting carboxylation of Rubisco. Ribulose-1,5-bisphosphate (RuBP) is the principal substrate in the Calvin cycle, catalyzed by the enzyme Rubisco. The concentrations of $\mathrm{CO}_{2}$ and $\mathrm{O}_{2}$ strongly affect the catalyzing reaction. If the $\mathrm{CO}_{2}$ concentration increases, more combinative positions of Rubisco are taken by $\mathrm{CO}_{2}$ and the rate of carboxylation (carbon-reduction of photosynthesis, PCR) increases, therefore, the rate of photosynthesis increases. Likewise, the ratio of $\left[\mathrm{O}_{2}\right] /\left[\mathrm{CO}_{2}\right]$ inside chloroplasts declines, passivating enzymes of glycolic acid cycle. Thus photorespiration (carbon-oxidation of photosynthesis, PCO) is restricted and net rate of photosynthesis increases. However, the results from this experiment suggest nitrogen has a bigger limiting effect on seedlings than carbon, in other words, even under elevated $\left[\mathrm{CO}_{2}\right]$, the nitrogen level will be also more pivotal. i.e., elevated $\left[\mathrm{CO}_{2}\right]$ promoted absorption of high nitrogen. This conclusion is consistent with the conclusions of Johnson et al. (2000, pp.117) and Demmers-Derks et al. (1998, pp.829). They found a similar lack of growth response to elevated $\left[\mathrm{CO}_{2}\right]$ at low nutrition supply (It was a $\mathrm{CO}_{2}$ and temperature study) Also see Lewis et al. (2003, pp.359), who did not find much response to $\mathrm{CO}_{2}$ and concluded that $\mathrm{N}$ was an important controlling factor.

In EC+LN condition $F_{\mathrm{v}} / F_{\mathrm{m}}$ was much lower but $C_{\mathrm{i}}$ was much higher comparing with that in $\mathrm{AC}+\mathrm{MN}$. The decline of $F_{\mathrm{v}} / F_{\mathrm{m}}$ is a remarkable characteristic of photosynthetic photoinhibition, and generally seemed as a criterion to judge if photoinhibition or not (Guo et al., 2005, pp.592). A similar decrease of $F_{\mathrm{v}} / F_{\mathrm{m}}$ under nitrogen-poor had also been found in larch (Guo et al., 2005, pp.589). A possible explanation for the high $C_{\mathrm{i}}$ is that when the $\mathrm{C} / \mathrm{N}$ ratio is imbalanced, photosynthetic substrates are reduced and yield less NADPH and ATP, suppressing the light reactions. At the same time, 
low nitrogen supply reduces Rubisco activity, the rate of carboxylation declines and assimilation of $\mathrm{CO}_{2}$ is reduced (Guo et al., 2005, pp.592). Thus, even with enough $\mathrm{CO}_{2}$ the $\mathrm{EC}+\mathrm{LN}$ treatment has less photosynthetic capacity and biomass than $\mathrm{EC}+\mathrm{MN}$ or $\mathrm{EC}+\mathrm{HN}$. Other studies have reported that photosynthetic acclimation, the shift to a decreased carboxylation capacity in elevated $\left[\mathrm{CO}_{2}\right]$, is more marked in nutrient-limited than in well-fertilized plants, and that elevated $\left[\mathrm{CO}_{2}\right]$ leads to a larger decrease of Rubisco in nitrogen-limited plants than in well-fertilized plants (Guo et al., 2005, pp.562). Elevated $\left[\mathrm{CO}_{2}\right]$ promoted growth of seedlings to a certain extent in the EC+LN treatment, but $\mathrm{N}$ availability was insufficient to allow full utilization of the increased $\left[\mathrm{CO}_{2}\right]$.

The investigation indicates that, as atmospheric $\left[\mathrm{CO}_{2}\right]$ increases, gas exchange and growth of white birch is responsive to nitrogen availability by a balanced $\mathrm{C} / \mathrm{N}$ ratio. In the future, nitrogen nutrition needs to be maintained for gaining greater productivity of plants.

\section{Acknowledgment}

The authors thank Robert Teskey for reviewing this paper.

\section{References}

Butler, W.L. (1978). Energy distribution in the photochemical apparatus of photosynthesis. Annual Review Plant Physiology, 29, 345-378.

Carswell, F.E., Grace, J., Lucas, M.E., and Jarvis, P.G. (2000). Interaction of nutrient limitation and elevated $\mathrm{CO}_{2}$ concentration on carbon assimilation of a tropical tree seedling (Cedrela odorata). Tree Physiology, 20, 977-986.

Crawford, N.M., and Glass, A.D.M. (1998). Molecular and physiological aspect of nitrate uptake in plants. Trends in Plant Science, 3, 389-395.

Demmers-Derks, H., Mitchell, R.A.C., Mitchell,V.J., and Lawlor, D.W. (1998). Response of sugar beet (Beta vulgaris L.) yield and biochemical composition to elevated $\mathrm{CO}_{2}$ and temperature at two nitrogen applications. Plant Cell and Environment, 21, 829-836.

Elizabeth, A.A., and Alistair, R. (2007). The response of photosynthesis and stomatal conductance to rising $\left[\mathrm{CO}_{2}\right]$ : mechanisms and environmental interactions. Plant Cell and Environment, 30(3), 258-270.

Guo, S.L., Yan, X.F., Bai, B., and Yu, S. (2005). Responses of larch seedling's photosynthetic characteristics to nitrogen and phosphorus deficiency. Chinese Journal of Applied Ecology, 16, 589-594.

Guo, S.W., Ran, W., Zhou, Y., and Shen, Q.R. (2006). On carbon and nitrogen metabolism of rice plants under elevated CO2 conditions. Chinese Journal of Rice Science, 20(5):560-566.

Hoagland, D.R., and Arnon, D.I. (1950). The water-culture method for growing plants without soil. Berkeley: University of California 347, pp.32.

Johnson, D.W., Cheng, W. and Ball, J.T. (2000). Effects of $\mathrm{CO}_{2}$ and $\mathrm{N}$ fertilization on decomposition and immobilization in ponderosa pine litter. Plant and Soil, 224, 115-122.

Jung, S., Steffen, K.L. and Lee, H.J. (1998). Comparative photoinhibition of a high and a low altitude ecotype of tomato (Lycopersicon hirsutum) to chilling stress under high and low light conditions. Plant Science, 134, 69-77.

Kaakinen, S., Jolkkonen, A., Iivonen, S., and Vapaavuori, E. (2004). Growth, allocation and tissue chemistry of Picea abies seedlings affected by nutrient supply during the second growing season. Tree Physiology, 24, 707-719.

King, J.S., Thomas, R.B., and Strain, B.R. (1996). Growth and carbon accumulation in root systems of Pinus taeda and Pinus ponderosa seedlings as affected by varying $\mathrm{CO}_{2}$ temperature, and nitrogen. Tree Physiology, 16, 635-642.

Küster, A., Schaible, R., and Schubert, H. (2004). Light acclimation of photosynthesis in three charophyte species. Aquatic Botany, 79, 111-124.

Lewis, J.D., Lucash, M., Olszyk, D.M. and Tingey, D.T. (2004). Relationships between needle nitrogen concentration and photosynthetic responses of Douglas-fir seedlings to elevated $\mathrm{CO}_{2}$ and temperature. New Phytologist, 162, 355-364.

\section{Li, H.S.(2000). Modern Plant Physiology. Beijing: Higher education press.}

Luomala, E.M., Laitinen, K., Vapaavuori, E., and Kellomäki, S. (2003). Variable photosynthetic acclimation in consecutive cohorts of Scots pine needles during three years of growth at elevated $\mathrm{CO}_{2}$ and elevated temperature. Plant Cell and Environment, 26, 645-660.

Maillard, P., Guehl, J.M., Muller, J.F., and Gross, P. (2001). Interactive effects of elevated $\mathrm{CO}_{2}$ concentration and nitrogen supply on partitioning of newly fixed ${ }^{13} \mathrm{C}$ and ${ }^{15} \mathrm{~N}$ between shoot and roots of pedunculate oak seedlings (Quercus robur). Tree Physiology, 21, 163-172.

Matamala, R., and Drake, B.G. (1999). The influence of atmospheric $\mathrm{CO}_{2}$ enrichment on plant-soil nitrogen interactions in a wetland plant community on the Chesapeake Bay. Plant and Soil, 210, 93-101. 
Murray, M.B., Smith, R.I., Friend, A., and Jarvis, P.G. (2000). Effect of elevated $\left[\mathrm{CO}_{2}\right]$ and varying nutrient application rates on physiology and biomass accumulation of Sitka spruce (Picea sitchensis). Tree Physiology, 20, $421-434$.

Teskey, R.O. (1997). Combined effects of elevated $\mathrm{CO}_{2}$ and air temperature on carbon assimilation of Pinus taeda trees. Plant Cell and Environment, 20, 373-380.

Uprety, D.C., and Mahalaxmi, V. (2000). Effect of Elevated $\mathrm{CO}_{2}$ and Nitrogen Nutrition on Photosynthesis, Growth and Carbon-Nitrogen Balance in Brassica juncea. J. Agron. Crop Sci.,184, 271-276.

Table 1. $P$-values of two-way ANOVA for the effects of $\left[\mathrm{CO}_{2}\right]$, nitrogen availability and their interaction on maximal net photosynthetic rate $\left(P_{\max }\right)$, respiration $\left(R_{\mathrm{d}}\right)$, intercellular $\left[\mathrm{CO}_{2}\right]\left(C_{\mathrm{i}}\right)$, photochemical efficiency of PSII $\left(F_{\mathrm{v}} / F_{\mathrm{m}}\right)$, Chlorophyll (Chl) $a+b, \mathrm{Chl} a, \mathrm{Chl} b$ and root, stem, leaf and total biomass of white birch seedlings. The seedlings were grown under two $\left[\mathrm{CO}_{2}\right](350 \mathrm{ppm}$ and $700 \mathrm{ppm})$ and three levels of nitrogen treatments (low, medium and high) for about three months.

\begin{tabular}{llll}
\hline Source of variance & $\mathrm{CO}_{2}$ & Nitrogen & $\mathrm{CO}_{2} \times$ Nitrogen \\
\hline$P_{\max }$ & 0.033 & $<0.0001$ & 0.073 \\
$R_{\mathrm{d}}$ & 0.301 & 0.861 & 0.922 \\
$C_{\mathrm{i}}$ & $<0.0001$ & 0.045 & 0.006 \\
$F_{\mathrm{v}} / F_{\mathrm{m}}$ & 0.734 & $<0.0001$ & 0.055 \\
$\mathrm{Chl} a+b$ & 0.147 & 0.350 & 0.003 \\
$\mathrm{Chl} a$ & 0.089 & 0.005 & 0.577 \\
Chl $b$ & 0.281 & 0.013 & 0.702 \\
Total biomass & 0.068 & $<0.0001$ & 0.472 \\
Root & 0.008 & $<0.0001$ & 0.401 \\
Stem & 0.613 & $<0.0001$ & 0.004 \\
Leaf & 0.228 & $<0.0001$ & 0.852 \\
Secondary root & 0.003 & $<0.0001$ & 0.871 \\
Primary root & 0.151 & $<0.0001$ & 0.429 \\
\hline
\end{tabular}

Table 2. Effects of $\left[\mathrm{CO}_{2}\right]$ and nitrogen treatments on chlorophyll contents $(\mathrm{Chl} a, \mathrm{Chl} b$, Chl $a+b)$ in white birch seedlings. Data represent the mean \pm SE of three replicates. See Figure 1 for other explanations.

\begin{tabular}{lllll}
\hline $\mathrm{CO}_{2}$ treatment & $\begin{array}{l}\text { Nitrogen } \\
\text { treatment } \\
\left(\mathrm{mmol} \mathrm{L}^{-1} \mathrm{~N}\right)\end{array}$ & $\begin{array}{l}\mathrm{Chl} a \\
\left(\mathrm{mg} \mathrm{g}^{-1}\right)\end{array}$ & $\begin{array}{l}\mathrm{Chl} b \\
\left(\mathrm{mg} \mathrm{g}^{-1}\right)\end{array}$ & $\begin{array}{l}\text { Chl } a+b \\
\left(\mathrm{mg} \mathrm{g}^{-1}\right)\end{array}$ \\
\hline Ambient $\left[\mathrm{CO}_{2}\right]$ & $0(\mathrm{LN})$ & $0.76 \pm 0.03 \mathrm{~b}$ & $0.23 \pm 0.01 \mathrm{~b}$ & $1.00 \pm 0.04 \mathrm{a}$ \\
& $1.5(\mathrm{MN})$ & $1.26 \pm 0.05 \mathrm{a}$ & $0.37 \pm 0.02 \mathrm{ab}$ & $1.63 \pm 0.07 \mathrm{a}$ \\
& $3(\mathrm{HN})$ & $1.58 \pm 0.37 \mathrm{a}$ & $0.51 \pm 0.15 \mathrm{a}$ & $2.09 \pm 0.52 \mathrm{a}$ \\
Elevated $\left[\mathrm{CO}_{2}\right]$ & $0(\mathrm{LN})$ & $0.72 \pm 0.09 \mathrm{~b}$ & $0.24 \pm 0.04 \mathrm{a}$ & $0.95 \pm 0.12 \mathrm{~b}$ \\
& $1.5(\mathrm{MN})$ & $0.89 \pm 0.24 \mathrm{a}$ & $0.29 \pm 0.07 \mathrm{a}$ & $1.18 \pm 0.31 \mathrm{a}$ \\
& $3(\mathrm{HN})$ & $1.25 \pm 0.07 \mathrm{a}$ & $0.41 \pm 0.02 \mathrm{a}$ & $1.67 \pm 0.07 \mathrm{a}$ \\
\hline
\end{tabular}




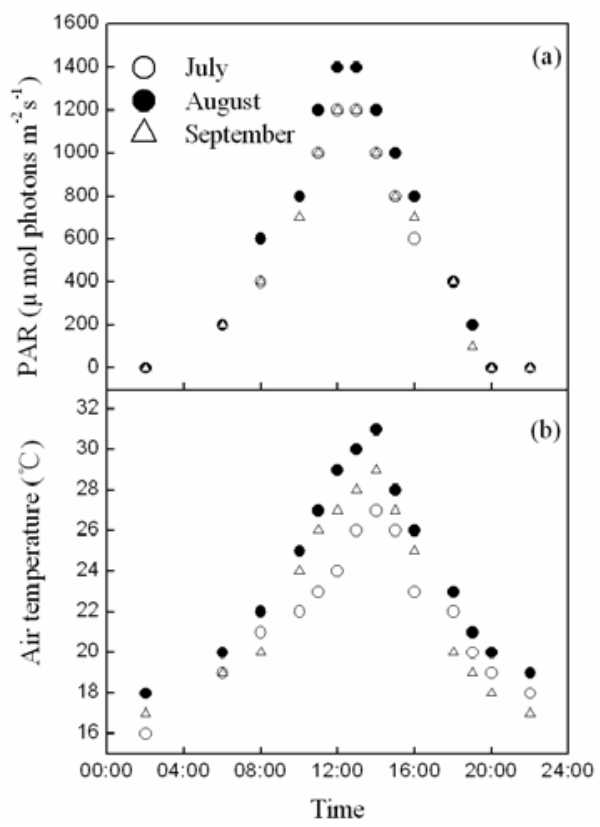

Figure 1. Diurnal pattern of (a) photosynthetically active radiation (PAR) and (b) air temperature during the experiment. The seedlings were grown under two $\left[\mathrm{CO}_{2}\right](350 \mathrm{ppm}$ versus $700 \mathrm{ppm})$ and three levels of nitrogen amendment, low (LN), medium $(\mathrm{MN})$ and high $(\mathrm{HN})$ for about three months.

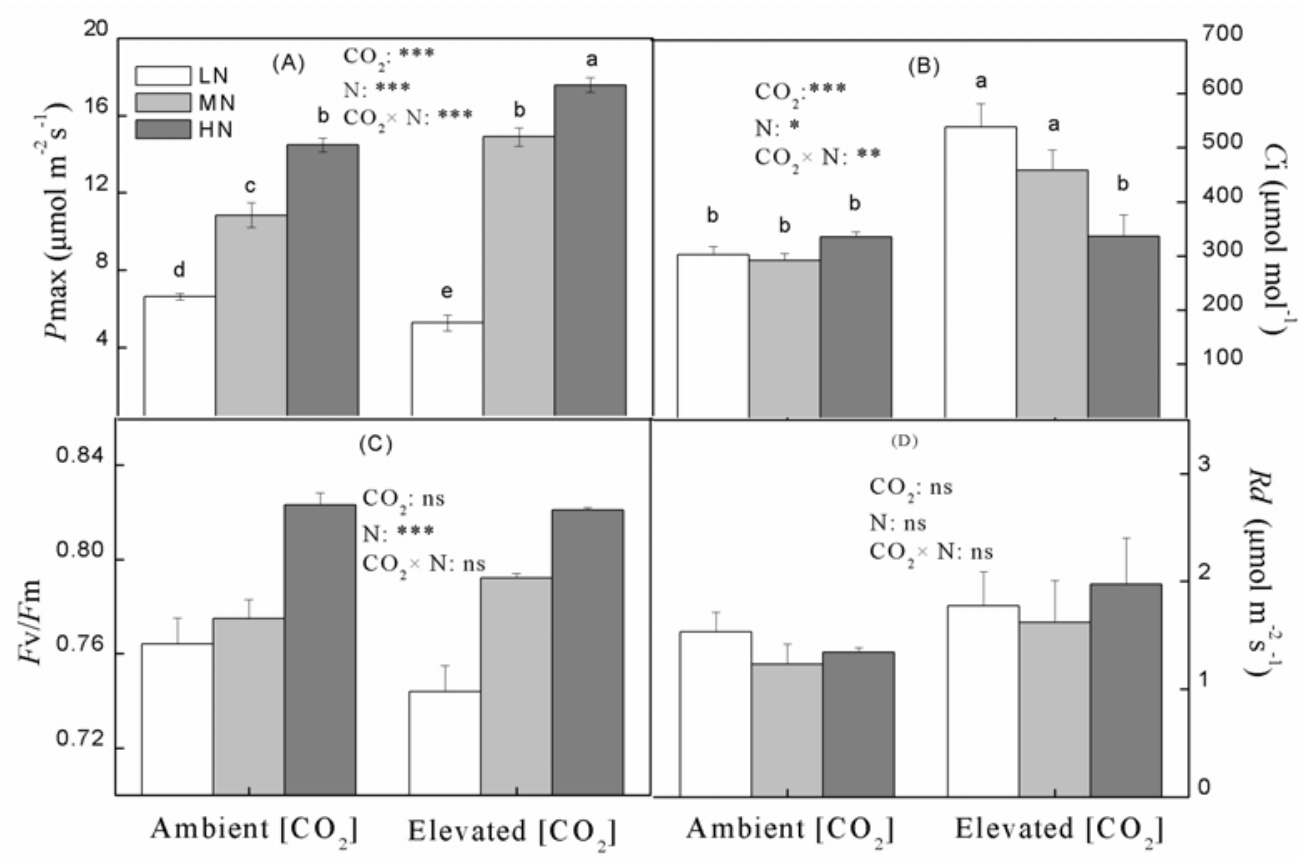

Figure 2. Effects of $\left[\mathrm{CO}_{2}\right]$ and nitrogen level on (A): maximal net photosynthetic rate $\left(P_{\max }\right)$, (B): intercellular $\mathrm{CO}_{2}$ concentration $\left(C_{\mathrm{i}}\right),(\mathrm{C})$ : maximum PS II efficiency $\left(F_{\mathrm{v}} / F_{\mathrm{m}}\right)$ and $(\mathrm{D})$ : respiration rate $\left(R_{\mathrm{d}}\right)$ in current-year-old white birch seedlings. The seedlings were grown under two $\left[\mathrm{CO}_{2}\right](350 \mathrm{ppm}$ versus $700 \mathrm{ppm})$ and three levels of nitrogen amendment, low $(\mathrm{LN})$, medium (MN) and high $(\mathrm{HN})$ for about three months. (mean $\pm \mathrm{SE}, \mathrm{n}=5$ ). Significance values $(*$ : $P<0.05$; **: $P<0.01 ; * * *: P<0.001$ and ns: $P>0.05)$ are based on two-way ANOVA. LSD test was conducted where there was a significant interaction between $\left[\mathrm{CO}_{2}\right]$ and nitrogen treatment. Means sharing the same letter are not significantly different from each other. 


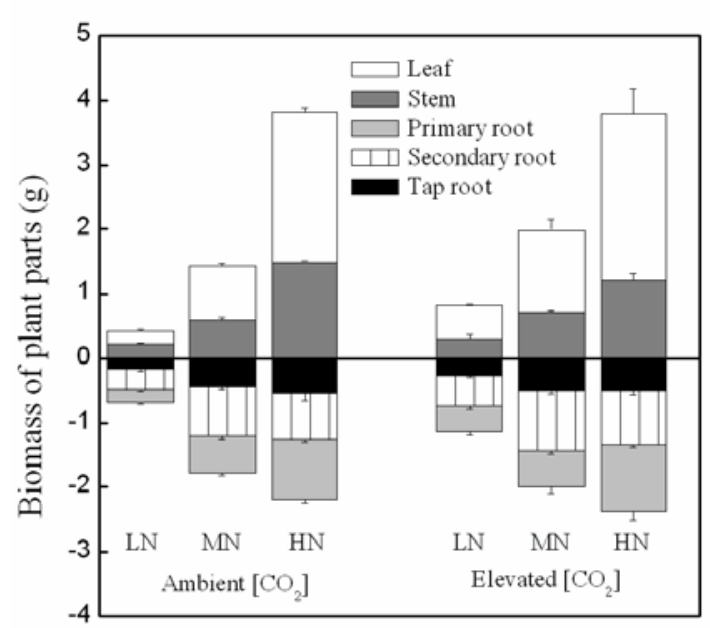

Figure 3. Aboveground (upper part of chart) and belowground (lower part of chart) biomass at two $\left[\mathrm{CO}_{2}\right](350 \mathrm{ppm}$ and $700 \mathrm{ppm}$ ) and three nitrogen treatments (low, medium and high). (Mean $\pm \mathrm{SE}, \mathrm{n}=5$ ). See Figure 1 for other explanations. 